\title{
PENGEMBANGAN ALAT BANTU KOMUNIKASI BAGI PENYANDANG DISABILITAS BUTA-TULI MENGGUNAKAN IMAP
}

\author{
Agung W. Setiawan', Abdullah F.A. Mubarok ${ }^{2}$, Akhmad D.H. Syababa ${ }^{3}$ \\ Teknik Biomedis ${ }^{1}$, Sekolah Teknik Elektro dan Informatika ${ }^{2}$, Institut Teknologi Bandung ${ }^{3}$ \\ Email: ${ }^{1}$ awsetiawan@ stei.itb.ac.id, ${ }^{2}$ abdulfaqihalm@gmail.com, ${ }^{3}$ akhmadyma@ students.itb.ac.id
}

(Naskah masuk: 19 November 2018, diterima untuk diterbitkan: 18 Desember 2018)

\begin{abstract}
Abstrak
Melalui UU Nomor 8 Tahun 2016, negara menjamin hak penyandang disabilitas, dimana salah satunya adalah hak berkomunikasi. Pada kasus disabilitas netra dan wicara, penyandang memiliki keterbatasan untuk berkomunikasi dengan normal. Salah satu arah penelitian yang sedang berkembang dalam bidang teknologi bantu adalah alat terhubung dengan internet. Oleh karena itu, pada penelitian ini dikembangkan sebuah alat bantu komunikasi dengan memanfaatkan simbol Braille yang terhubung internet menggunakan IMAP. Alat ini diharapkan dapat membantu komunikasi antara penyandang buta-tuli dengan kerabat/sahabat. Pada penelitian ini, dikembangkan sebuah Braille keyboard, berupa push button yang disusun sesuai dengan Braille cell. Braille keyboard ini digunakan sebagai devais masukan bagi penyandang buta-tuli. Di sisi kerabat/sahabat, digunakan QWERTY keyboard untuk mengetik kata atau kalimat yang ingin disampaikan ke penyandang buta-tuli. Kedua keyboard tersebut terhubung ke sebuah mikrokomputer, Raspberry Pi 3. Ini merupakan skema offline, dimana penyandang dan kerabat/sahabat berada dalam satu tempat. Skema yang kedua adalah online, pada skema ini penyandang butatuli dan kerabat/sahabat dapat saling mengirimkan informasi berupa teks melalui koneksi internet berbasis IMAP (e-mail). Pada penelitian ini juga dikembangkan sebuah Braille display yang terdiri dari enam buah motor vibrasi yang dipasang pada tubuh penyandang. Pola getaran motor dari Braille display ini sesuai dengan susunan Braille cell. Sedangkan untuk kerabat/sahabat, dapat melihat informasi/kata di sebuah LCD atau e-mail. Tahapan pengembangan selanjutnya adalah prototipe dibuat menjadi bentuk dan ukuran yang lebih ringkas, modul Braille keyboard disesuaikan dengan jarak standar dan dilengkapi dengan modul text-to-speech.
\end{abstract}

Kata kunci: alat bantu, komunikasi, penyandang buta-tuli, motor braille display, internet, braille keyboard

\section{DEVELOPMENT OF COMMUNICATION ASSISTIVE DEVICE FOR DEAFBLIND PEOPLE USING IMAP}

\begin{abstract}
Law Number 8, 2016 on Persons with Disabilities, The Government of Indonesia has guaranteed the rights of peoples with disablities to communicate. People with deaf-blindness has limitation to communicate normally. The trend in development of assistive technology device is to connect it to internet. Therefore, purpose of this research is to develop an assistive technology device which utilized Braille Alphabet and connected to the internet using IMAP. It is expected that the device could link the communication between people with deafblind and their relatives. In this research, a Braille keyboard is developed and used as input device for people with deafblind. For the relatives, they use a standard QWERTY keyboard to type the word $(s)$ that will be conveyed to the people with deafblind. Those two keyboards are connected to a microcomputer, Raspberry Pi 3. This is the first communication scheme, the offline scheme, people with deafblind and relatives is in the same place. The second one is online scheme, people with deafblind and relatives could send text message through internet connection using IMAP. In this research, a Braille display is developed to convert the Latin alphabet to Braille alphabet through six vibration motors that are arranged according to Braille cell. For relatives, they could show the word(s) that is sent by the people with deafblind through LCD or their e-mail. Further development for the research is to develop more compact device and equipped with text-to-speech module. The last proposed development is to develop and implement the Braille keyboard that has standardized button.
\end{abstract}

Keywords: assistive device, communications, people with deafblind, motor braille display, braille keyboard 


\section{PENDAHULUAN}

Menurut Undang-Undang Republik Indonesia Nomor 8 Tahun 2016 tentang Penyandang Disabilitas (UU Nomor 8 Tahun 2016) pasal 1 ayat 1 yang dimaksud dengan penyandang disabilitas adalah setiap orang yang mengalami keterbatasan fisik, intelektual, mental, dan/atau sensorik dalam jangka waktu lama yang dalam berinteraksi dengan lingkungan dapat mengalami hambatan dan kesulitan untuk berpartisipasi secara penuh dan efektif dengan warga negara lainnya berdasarkan kesamaan hak. Keterbatasan yang dimiliki penyandang disabilitas ini meliputi disabilitas pada ragam fisik, intelektual, mental, dan sensorik. Menurut UU No. 8 Th. 2016, definisi penyandang disabilitas sensorik adalah terganggunya salah satu fungsi dari panca indera, antara lain disabilitas netra, disabilitas rungu, dan/atau disabilitas wicara. Berdasarkan data yang diperoleh dari Survei Sosial Ekonomi Nasional (Susenas) tahun 2012 yang dilakukan oleh Badan Pusat Statistik (BPS), mayoritas penyandang disabilitas di Indonesia merupakan penyandang dengan lebih dari satu jenis keterbatasan, yaitu sebesar 39,97\%.

Pada kasus disabilitas netra dan wicara, penyandang disabilitas memiliki keterbatasan untuk berkomunikasi dengan orang lain, karena faktor penglihatan dan pendengaran yang tidak berfungsi dengan baik. Sementara, negara telah menjamin hak penyandang disabilitas melalui UU No. 8 Tahun 2016, yaitu hak hidup secara mandiri dan dilibatkan di masyarakat serta hak berekspresi, berkomunikasi, dan memperoleh informasi. Oleh karena itu, untuk memberikan solusi atas permasalahan tersebut, pada penelitian ini dikembangkan sebuah alat bantu komunikasi yang memanfaatkan simbol braille. Pada pasal 1 ayat 10 UU No. 8 Tahun 2016 juga telah didefinisikan pengertian alat bantu, yaitu benda yang berfungsi membantu kemandirian penyandang disabilitas dalam melakukan kegiatan sehari-hari. Alat ini diharapkan dapat membantu komunikasi antara penyandang buta-tuli dengan orang sekitar, khususnya kerabat dan sahabat.

Salah satu penelitian mengenai alat bantu komunikasi untuk penyandang buta-tuli adalah GlovePi (Lorenzo Monti dan Giovanni Delnevo, 2018). Salah satu fitur alat ini adalah penyandang buta-tuli dapat melakukan komunikasi ke satu atau beberapa sahabat/kerabat. Alat ini menggunakan sensor sentuh kapasitif yang dipasang pada sebuah sarung tangan dan terhubung ke sebuah Raspberry Pi. Selain itu, GlovePi juga dilengkapi dengan aplikasi berbasis Android yang berfungsi untuk mengubah alfabet Malossi menjadi teks.

Pada penelitian yang lain, dikembangkan alat bantu komunikasi untuk penyandang buta-tuli menggunakan sensor tekanan yang dipasang pada sebuah sarung tangan. Selain itu, pada sarung tangan tersebut juga dilengkapi dengan motor mikro yang digunakan sebagai salah satu bentuk komunikasi, motor akan bergetar apabila ada kerabat/sahabat yang melakukan komunikasi (Ozioko \& Hersh, 2015).

Selain itu, terdapat penelitian lain yang juga memanfaatkan getaran. Getaran ini diperoleh dari fitur vibrasi yang terdapat di komputer tablet. Pada alat bantu ini, antarmuka perangkat keras yang digunakan oleh penyandang buta-tuli berupa saklar terkendali. Masukan dari saklar ini berupa durasi waktu dan kombinasi pulsa panjang-pendek. Sedangkan di sisi sahabat/kerabat, digunakan bluetooth keyboard (Hatakeyama, dkk, 2015).

Disamping itu, terdapat penelitian lain yang mengembangkan alat bantu komunikasi untuk penyandang buta-tuli menggunakan QWERTY keyboard dan Braille keypad. Kerabat/sahabat mengetikkan kata/kalimat dengan menggunakan QWERTY keyboard yang diubah menjadi huruf Braille dan ditampilkan ke sebuah Braille display. Sedangkan komunikasi dari penyandang buta-tuli ke kerabat/sahabat dilakukan dengan menggunakan Braille keypad. Huruf Braille keluaran keypad ini diubah menjadi teks dan ditampilkan ke LCD atau diubah menjadi suara melalui speaker (Anuradha \& Devibalan, 2016).

Pada saat ini, sangat sedikit penelitian di bidang teknologi bantu (assistive technology) yang memungkinkan akses internet bagi penyandang butatuli. Akses internet untuk penyandang buta-tuli masih berada dalam tahap awal pengembangan dan ditujukan untuk fungsi yang spesifik (Perfect, dkk, 2018).

Berdasarkan studi pustaka yang telah dilakukan, salah satu peluang yang dapat dilakukan untuk membantu penyandang disabilitas buta-tuli adalah mengembangkan alat bantu komunikasi yang dilengkapi dengan akses internet. Salah satu bentuk protokol komunikasi yang banyak dan mudah digunakan adalah Internet Message Access Protocol (IMAP). Oleh karena itu, pada penelitian dikembangkan alat komunikasi yang ditujukan untuk penyandang buta-tuli menggunakan IMAP.

\section{SPESIFIKASI SISTEM}

Pada penelitian ini, modul Braille yang digunakan adalah modul Braille grade 1. Alat bantu komunikasi ini dirancang dapat mengakomodasi komunikasi antara penyandang buta-tuli dengan orang lain. Komunikasi tersebut dilakukan dengan menggunakan sebuah mikrokomputer, Raspberry Pi 3 , yang terhubung dengan jaringan internet. Raspberry Pi 3 ini terhubung dengan modul masukan dan keluaran Braille. Modul masukan Braille berupa push button yang dirangkai sesuai dengan konfigurasi standar Braille cell, $3 \times 2$. Sedangkan modul keluaran Braille yang digunakan berupa sebuah body Braille yang dirancang supaya dapat diletakkan pada bagian tubuh (bagian perut) penyandang buta-tuli. Hal ini dilakukan untuk mendapatkan kepraktisan dan kemudahan pemakaian alat bantu bagi penyandang buta-tuli (Ohtsuka, dkk, 2008). 
Salah satu fitur alat bantu ini adalah penyandang buta-tuli dapat mengirimkan informasi berupa teks menggunakan Braille keyboard dan gambar kondisi sekitar dengan modul kamera kepada kerabat/sahabat yang dikirimkan menggunakan aplikasi pengirim pesan yang sudah ada. Sehingga, isu/masalah privasi terkait penggunaan kamera dapat diminimalkan, karena penyandang disabilitas sendiri yang akan menentukan akan mengirim ke siapa. Salah satu riset yang telah dilakukan oleh peneliti yang lain yaitu sistem "Helen Keller Phone", dimana penyandang disabilitas buta-tuli dapat berkomunikasi dengan orang lain melalui koneksi internet menggunakan aplikasi Skype (Ohtsuka, dkk, 2012).

Dengan menggunakan alat bantu komunikasi ini, kerabat-sahabat juga dapat berkomunikasi, mengirim email ke penyandang. Teks yang ada di email akan dikonversi menjadi kode Braille yang dapat dimengerti oleh penyandang. Disamping itu, kerabat-sahabat juga dapat berkomunikasi secara langsung kepada penyandang buta-tuli melalui QWERTY keyboard yang terletak di samping penyandang. Untuk mempermudah komunikasi, pada alat bantu ini juga disediakan sebuah LCD display yang digunakan untuk menampilkan teks yang ditulis oleh penyandang pada saat mengetik menggunakan Braille keyboard. Diagram blok alat bantu komunikasi penyandang buta-tuli yang dikembangkan dalam penelitian ini dapat dilihat pada Gambar 1 .

Pada penelitian ini, terdapat tiga pertimbangan yang diambil dalam merancang dan merealisasikan alat bantu komunikasi untuk penyandang buta-tuli ini, yaitu:

1. Mudah digunakan,

2. Harga terjangkau,

3. Tidak membutuhkan perawatan yang intensif.

Selain itu, alat bantu komunikasi penyandang buta-tuli dirancang seringkas mungkin. Pada penelitian yang lain, digunakan servo motor untuk menghasilkan ekstrasi informasi berupa susunan braille ke penyandang buta-tuli (Anuradha \& Devibalan, 2016). Pada penelitian ini digunakan vibration motor berukuran $10 \mathrm{~mm}$, karena jauh lebih kecil jika dibandingkan menggunakan servo motor. Sehingga penyandang buta-tuli dapat membaca informasi susunan Braille.

Pada tahap penelitian ini, luaran penelitiannya masih berupa working prototype. Karena masih berupa penelitian awal, maka pada tahap ini terdapat beberapa batasan dalam merealisasikan alat bantu ini, yaitu:

1. Komunikasi yang dapat dilakukan hanya huruf Braille dasar.

2. Pengguna, yakni penyandang buta-tuli, diasumsikan telah mendapatkan pendidikan huruf Braille sebelumnya.

3. Koneksi internet masih menggunakan WiFi. Adapun alasan pemilihan Wi-Fi sebagai koneksi data internet karena pada Raspberry Pi 3 sudah dilengkapi dengan modul Wireless LAN adapter. Apabila menggunakan modul modem GSM, maka diperlukan biaya tambahan dan harganya relatif mahal (sama dengan satu Raspberry Pi 3). Hal ini mengakibatkan penggunaan alat hanya bisa dilakukan pada area yang terbatas (memiliki koneksi Wi-Fi). Kekurangan ini masih bisa diselesaikan dengan cara menggunakan fasilitas Wi-Fi tethering yang sudah ada di smartphone.

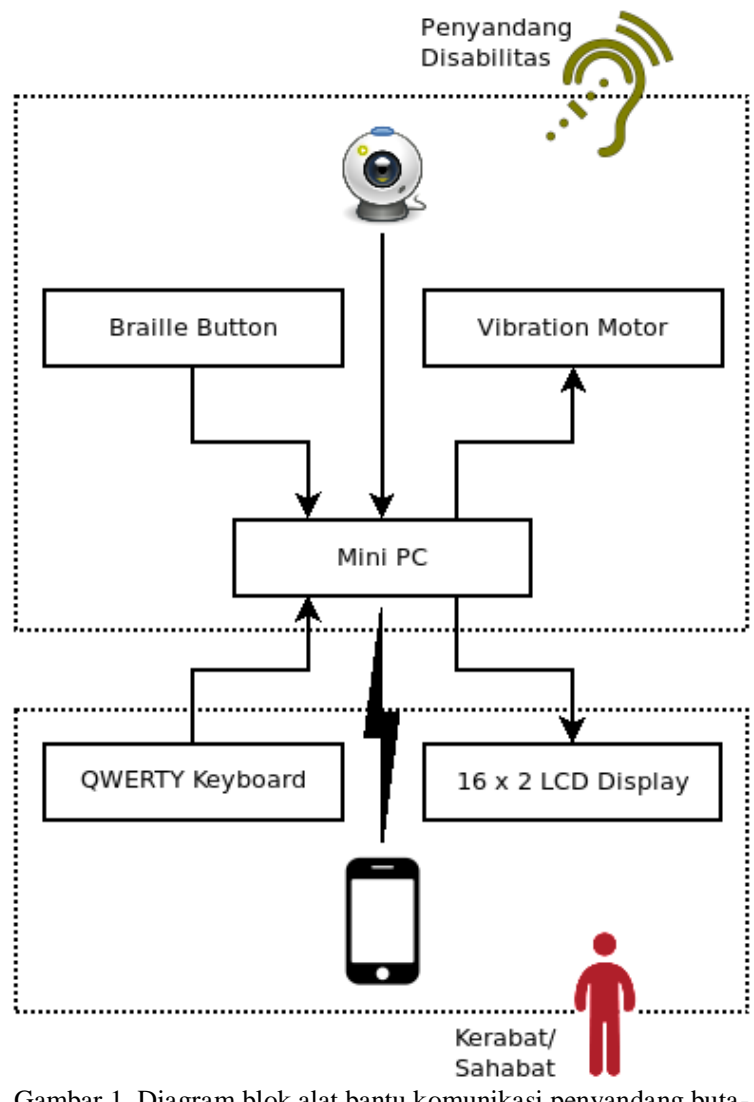

Gambar 1. Diagram blok alat bantu komunikasi penyandang butatuli.

Salah satu kriteria yang digunakan dalam penelitian ini adalah akurasi keterbacaan body Braille display yang berupa vibration motor. Untuk memastikan tingkat keakurasian yang baik, peletakan modul body Braille display ini haruslah di tempat tepat. Berdasarkan studi yang telah dilakukan, modul body braille display diharapkan dapat mencapai persentase keterbacaan sebesar $80 \%$ (Ohtsuka, dkk, 2008). Untuk mendapatkan akurasi yang sesuai dengan kriteria tersebut, pada penelitian ini dipilih body Braille display dengan menggunakan enam buah motor vibrasi.

\section{REALISASI SISTEM}

\subsection{Realisasi Braille keyboard dan display}

Braille keyboard terdiri dari enam tombol untuk input karakter braille, tombol reset, tombol spasi, dua 
tombol pengaturan e-mail, dan tombol konfirmasi. Pada penelitian ini digunakan push button karena mudah diperoleh serta relatif lebih murah. Peletakan push button ini dirancang sedemikian rupa sehingga penyandang disabilitas dapat menggunakannya dengan mudah.

Pada rangkaian Braille keyboard, digunakan skema pulldown resistor untuk menghindari nilai float pada masukan (push button). Keluaran dari Braille keyboard tersebut menentukan nilai masukan pin General-Purpose Input/Output (GPIO). Masukan ini akan bernilai HIGH ketika push button ditekan dan bernilai $L O W$ pada keadaan sebaliknya. Pada penelitian ini, digunakan resistor bernilai $1 \mathrm{k} \Omega$ yang ditempatkan pada pin masukan GPIO. Resistor ini berfungsi sebagai pengaman yang akan mengecilkan arus listrik yang masuk ke Raspberry Pi 3.

Pada penelitian ini, Braille keyboard yang dirancang terdiri dari enam buah tombol berupa push

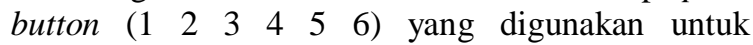
merepresentasikan Braille cell sebagai standar susunan pola huruf Braille. Selain itu, terdapat pula tombol lain untuk memberikan beberapa perintah tertentu, yaitu:

- $O K$, digunakan untuk menampilkan teks yang diketik dengan Braille button pada layar LCD.

- $\quad C H E C K$, digunakan untuk mengecek adanya $e$-mail baru yang masuk pada layanan $e$-mail.

- $\quad S E N D$, digunakan untuk mengirimkan pesan melalui $e$-mail (pada rancangan tahap ini belum terimplementasi).

- SPACE, digunakan untuk mengetikkan karakter spasi pada pesan.

- RESET, digunakan untuk mengatur ulang modul atau membatalkan pesan yang ditulis.

Gambar 2(a) memperlihatkan susunan Braille Cell. Tombol-tombol yang direalisasikan menggunakan push button dan masih diimplementasikan dalam sebuah breadboard dapat dilihat pada Gambar 2(b).

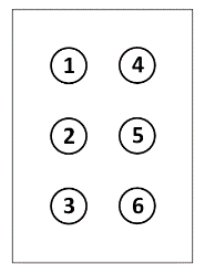

(a)

Gambar 2. (a) Braille cell, (b) Braille keyboard.

Braille display merupakan sarana bagi penyandang buta-tuli menerima informasi. Braille display ini terdiri dari enam vibration motor yang masing-masing dapat diatur On atau Off melalui GPIO dari Raspberry Pi 3. Untuk dapat menjalankan motor vibrasi, digunakan transistor BJT 2N222. Hal ini penting dilakukan karena pin GPIO dari Raspberry Pi 3 hanya mampu memberikan arus maksimum sebesar $16 \mathrm{~mA}$. Pada modul ini juga digunakan dioda tipe 1N4001 sebagai penyearah arus, yang digunakan sebagai pengaman, sehingga arus dari motor tidak dapat masuk ke Raspberry Pi 3. Selain itu, terdapat kapasitor yang dirangkai paralel dengan dioda dan motor vibrasi, yang berfungsi untuk menampung tegangan spike saat menjalankan motor vibrasi. Pola getaran motor dari Braille display ini disusun sesuai dengan pola Braille Cell.

\subsection{Implementasi E-mail Parsing}

Pada penelitian ini, digunakan bahasa pemrograman Python. Beberapa modul perangkat lunak yang digunakan dalam alat bantu komunikasi ini adalah modul Inter-integrated Circuit $\left(\mathrm{I}^{2} \mathrm{C}\right)$ untuk LCD, modul e-mail parsing, modul message parsing, dan beberapa library file lainnya yang sudah umum digunakan pada Raspberry Pi 3.

Pada pengembangan purwarupa alat bantu komunikasi ini digunakan IMAPClient package yang menggunakan sebuah package lain, yaitu imaplib yang terdapat pada python standard library. Package tersebut dipilih karena pada IMAPClient sudah terdapat application programming interface (API), sehingga pengerjaan modul $e$-mail parsing ini lebih mudah dan mempersingkat waktu pengerjaan. Disamping itu, salah satu keuntungan penggunaan package ini adalah sudah terdapat exception module untuk mempermudah penanganan apabila terjadi suatu kesalahan.

Diagram alir proses $e$-mail parsing dapat dilihat pada Gambar 3. Tahap awal yang harus dilakukan pada penggunaan IMAPClient API adalah melakukan instance pada IMAPClient class. Langkah selanjutnya adalah membuat koneksi ke sebuah akun IMAP yang akan digunakan untuk melakukan interaksi dengan mail server. Pada penelitian, digunakan google mail server, salah satu pertimbangan utamanya adalah mail server ini banyak digunakan dan pengaturannya yang relatif lebih mudah. Pada penelitian ini juga digunakan Secure Socket Layers (SSL) sebagai protokol keamanan. Setelah client terhubung dengan server, client akan melakukan pencarian $e$-mail dengan tanda "UNSEEN". Proses selanjutnya adalah melakukan pengecekan subyek e-mail. Untuk mempermudah pembuatan program, pada penelitian ini hanya $e$-mail dengan subyek tertentu saja yang akan diproses oleh IMAPClient. Pada penelitian ini, ditentukan subyek e-mail yang digunakan adalah "Tubes". Apabila terdapat subyek $e$-mail selain "Tubes", maka $e$-mail tersebut tidak akan diproses oleh IMAPClient. Apabila subyek e-mail telah sesuai, maka langkah berikutnya adalah melakukan proses $e$-mail parsing terhadap e-mail payload. Hasil dari proses ini adalah hanya badan teks $e$-mail yang akan ditampilkan pada terminal. Proses e-mail parsing yang ditampilkan pada sebuah terminal dapat dilihat pada Gambar 4 . 


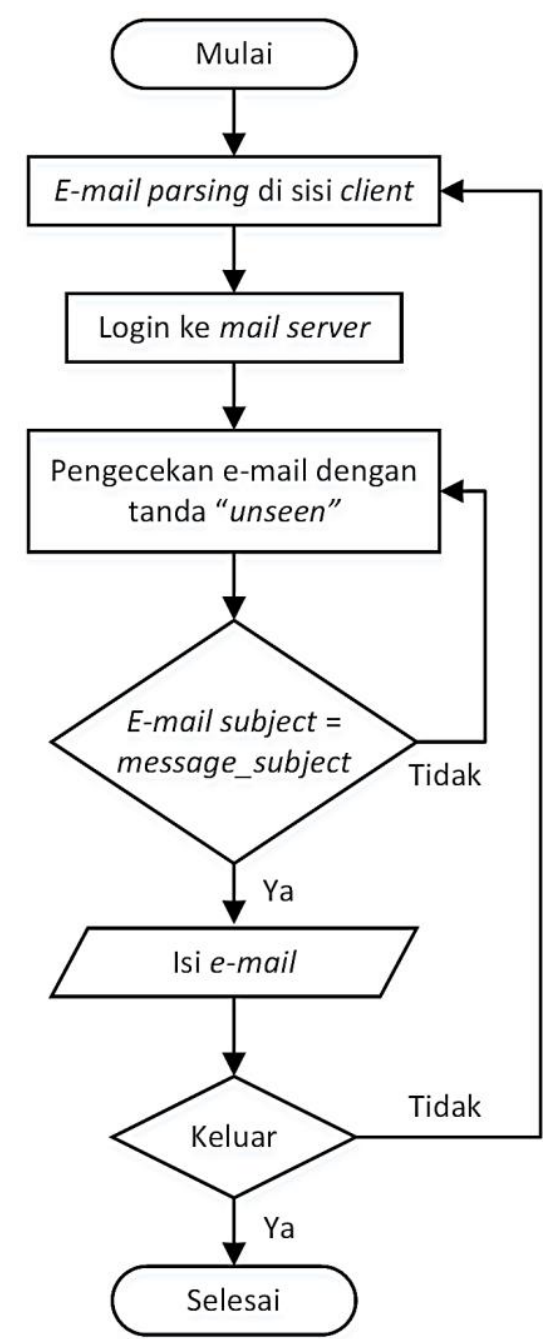

Gambar 3. Diagram alir e-mail parsing.

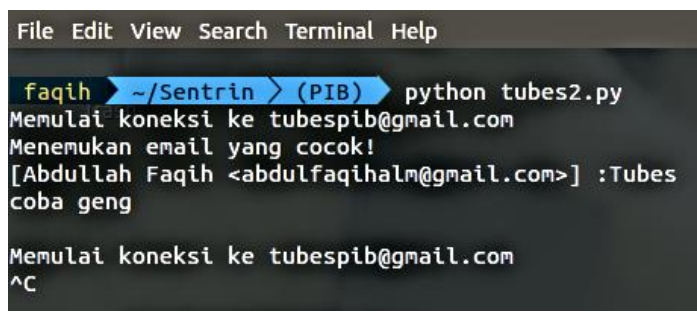

Gambar 4. Contoh proses e-mail parsing.

\section{PENGUJIAN DAN ANALISIS}

Pada penelitian ini, telah berhasil dikembangkan sebuah working protype alat bantu komunikasi untuk penyandang disabilitas buta-tuli. Purwarupa ini terdiri dari beberapa bagian, yaitu modul Braille keyboard, Braille display, dan $e$-mail parsing.

Pada penelitian awal ini, tombol-tombol Braille keyboard diimplementasikan menggunakan push button yang masih diimplementasikan dalam sebuah breadboard. Meskipun demikian, Braille keyboard tersebut sudah dapat berfungsi dengan baik. Pada tahap ini, desain printed circuit board (PCB) untuk rangkaian keyboard ini sudah dibuat, tetapi belum sempat dicetak.
Selanjutnya dilakukan pengujian pada modul $e$ mail parsing. Pada penelitian ini tidak dibuat fasilitas mail server sendiri. Pengiriman e-mail dilakukan menggunakan fasilitas aplikasi dan mail server yang telah tersedia. Karena fokus penelitian ini terletak pada modul e-mail parsing, bukan pembuatan mail server. Selain itu, hal ini dilakukan untuk mengurangi kompleksitas sistem yang dikembangkan.

Pada saat melakukan pengujian modul Braille display, ditemukan bahwa arus listrik yang diberikan Raspberry Pi 3 ke motor vibrator tidak mencukupi untuk menggerakkan keenam motor vibrator. Setelah dilakukan troubleshooting, diperoleh hasil bahwa arus listrik yang disuplai oleh Raspberry Pi 3 hanya mampu untuk mengaktifkan satu motor vibrator. Hal ini dikarenakan maksimum arus listrik keluaran dari Raspberry Pi 3 hanya sebesar $50 \mathrm{~mA}$. Sementara, satu motor vibrator memerlukan arus tipikal sebesar 40 mA. Oleh karena itu, diperlukan sumber arus eksternal. Pada penelitian ini digunakan sebuah baterai.

Seperti telah disebutkan sebelumnya, penelitian ini masih dalam tahap awal pengembangan purwarupa, sehingga masih terdapat beberapa kekurangan yang perlu diselesaikan. Disamping itu, pengujian yang dilakukan baru pada aspek fungsionalitas alat (proof of concept) dan belum diujicobakan ke penyandang buta-tuli secara langsung. Hal tersebut akan dilakukan pada tahap penelitian selanjutnya. Fokus utama dalam penelitian awal ini adalah mengembangkan alat bantu komunikasi untuk penyandang buta-tuli dengan menggunakan komponen/modul elektronika yang tersedia di Indonesia.

\section{KESIMPULAN DAN PENGEMBANGAN LANJUTAN}

Purwarupa alat bantu komunikasi untuk penyandang buta-tuli yang dikembangkan telah berhasil menjalankan beberapa fungsi utama, yaitu Braille keyboard, Braille display, LCD display, dan $e$-mail parsing dengan subyek e-mail tertentu. Pada tahap ini, alat bantu komunikasi ini belum diujicobakan secara langsung ke penyandang butatuli. Karena penelitian ini masih dalam tahap penelitian awal, dimana salah satu fokus utamanya adalah pengembangan sebuah working prototype. Disamping itu, masih perlu menambahkan fitur dan pengujian aspek keamanan alat.

Tahapan pengembangan selanjutnya adalah pengembangan sebuah purwarupa yang memiliki bentuk dan ukuran yang lebih ringkas, sehingga memudahkan pengguna dalam memakai alat bantu ini. Pada modul Braille keyboard, jarak antar tombol juga perlu disesuaikan dengan standar, sehingga mempermudah pengguna. Hal ini memerlukan komponen push button dengan dimensi yang lebih kecil, dan perlu dicari ketersediannya di pasar lokal maupun luar negeri. Dan ini tentu memerlukan biaya pengembangan yang lebih besar, terutama untuk 
komponen elektronika berukuran kecil untuk mengakomodasi ukuran standar Braille cell, diperlukan komponen berjenis surface-mount device (SMD). Selain itu, pencetakan PCB juga perlu dilakukan di luar negeri, karena jarak antar komponen yang semakin kecil memerlukan mesin pencetak PCB dengan akurasi dan presisi yang lebih tinggi. Pengembangan lainnya adalah alat juga dilengkapi dengan modul text-to-speech, sehingga kerabatsahabat langsung mengetahui maksud penyandang disabilitas tanpa perlu melihat ke layar LCD.

\section{DAFTAR PUSTAKA}

ANURANDHA, P.G. \& DEVIBALAN, K., 2016. A Low Cost Portable Communication Device for The Deafblind. International Journal of Industrial Electronics and Electrical Engineering, Special Issue (2016), pp.2225. Iran.

HATAKEYAMA, T., WATANABE T., TAKAHASHI, K., DOI, K., dan FUKUDA, A., 2015. Development of Communication Assistive Technology for Persons with Deaf-Blindness and Physical Limitation. Studies in Health Technology and Informatics. Europe PMC, Vol. 217, pp. 974-979.

Kementerian Kesehatan Republik Indonesia, 2014.

Buletin Jendela Data dan Informasi

Kesehatan: Situasi Penyandang Disabilitas. Jakarta: Kementerian Kesehatan Republik Indonesia.

MONTI, L. dan DELNEVO, G., 2018. On improving GlovePi: Towards a many-to-many communication among deaf-blind users. 2018 15th IEEE Annual Consumer Communications \& Networking Conference (CCNC). IEEE, pp. 1-5.

OZIOKO, O. \& HERSH, M., 2015. Development of a Portable Two-Way Communication and Information Device for Deafblind People. Studies in health technology and informatics. IOS Press, Vol. 217, pp. 51825.

OHTSUKA S., SASAKI N., HASEGAWA S., and HARAKAWA T., 2008. Body-Braille System for Disabled People. International Conference on Computers for Handicapped Persons (ICCHP) 2008, pp.682-685. Berlin: Springer.

OHTSUKA, S., SASAKI, N., HASEGAWA, S., HARAKAWA, T., 2012. Helen Keller Phone-a communication system for deafblind people using Body-Braille and Skype. 2012 IEEE Consumer Communications and Networking Conference (CCNC), pp.30-31. IEEE.
PERFECT E., JAISWAL, A., \& DAVIES, T.C., 2018. Systematic review: Investigating the effectiveness of assistive technology to enable internet access for individuals with deafblindness. Journal on Assistive Technology, pp. 1-10. Taylor \& Francis.

RAMIREZ- GARIBAY, F., OLIVARRIA, C.M., ALEJANDRO, E., \& JOEL, J.C., 2014. MyVox - Device for the communication between people: Blind, deaf, deaf-blind and unimpaired. Proceedings of the 4th IEEE Global Humanitarian Technology Conference, GHTC 2014. IEEE, pp. 506509.

Undang-undang Republik Indonesia nomor 6 tahun. 2016 tentang Penyandang Disabilitas. Jakarta: Kementerian Sekretariat Negara Republik Indonesia. 